\title{
Infrageneric classification of Quercus (Fagaceae) and typification of sectional names
}

\author{
KC Nixon \\ LH Bailey Hortorium, Cornell University, Ithaca, NY 14853, USA
}

\begin{abstract}
Summary - The genus Quercus $L$ (the true oaks) is widespread in the Northern hemisphere, in habitats ranging from temperate and tropical forests to dry thorn scrub and semi-desert. As far as is known, all species are anemophilous. The genus is most closely related to Trigonobalanus Forman, Colombobalanus Nixon and Crepet, and Formanodendron Nixon and Crepet, 3 extant tropical monotypic genera. The oldest unequivocal oak fossils are Oligocene in age, although fossilized catkins and stellate trichomes that may represent earlier Quercus are preserved in Baltic amber, of uncertain Early Tertiary age. Trigonobalanoid fossils are known from the Oligocene and Paleocene of North America, and later deposits in Europe. A subgeneric and sectional classification of Quercus that is slightly modified from that proposed by Camus is most consistent with recent phylogenetic analyses within Quercus. Such a classification recognizes 2 subgenera, Quercus and Cyclobalanopsis (Oersted) Schneider. The latter is restricted to eastern Asia and Malesia. Subgenus Quercus is divided into sections Lobatae Loudon (red oaks: North and South America), Protobalanus (Trelease) Schwarz (intermediate oaks: western North America), and Quercus (white oaks: E and W hemispheres). Two groups of white oaks that are sometimes recognized as sections, /lex (Eurasia), and Cerris (Eurasia) are considered part of section Quercus, but merit subsectional or higher rank following more complete analyses.
\end{abstract}

\section{Quercus / taxonomy / phylogeny / subgenera / sections}

Résumé - Classification à l'intérieur du genre Quercus et caractérisation des noms de sections. Le genre Quercus (les vrais chênes) couvre l'ensemble de l'hémisphère nord et colonise des habitats allant des forêts tempérées et tropicales aux formations arbustives et semi désertiques. D'après les connaissances acquises à ce jour, toutes les espèces sont anémophiles. Le genre est proche de 3 genres tropicaux monotypiques vivants : Trigonobalanus Forman, Colombobalanus Nixon et Crepet et Formanodendron Nixon et Crepet. Les restes fossiles les plus âgés datent de loligocène, bien que des chatons et des trichomes étoilés susceptibles de représenter le genre Quercus et datés de manière imprécise du début du tertiaire aient été préservés dans de l'ambre de la mer Baltique. Des fossiles trigobalanoides datant de l'oligocène et du paléogène en Amérique du Nord et des dépôts postérieurs en Europe ont été reconnus. La classification en sous-genres et en sections, tenant compte des analyses phylogénétiques récentes, est proche de celle proposée par Camus. Cette classification comprend 2 sous-genres, Quercus et Cyclobalanopsis (Oersted). Le dernier n'est représenté qu'en Asie. Le sous-genre Quercus est divisé en 3 sections : Lobatae Loudon (chênes rouges : Amérique du Nord et du Sud), Protobalanus (Trelease) Schwarz (chênes intermédiaires : Amérique du Nord occidentale) et Quercus (chênes blancs : hémisphères est et ouest). Deux groupes de chênes blancs souvent classés dans les chênes blancs comme sections, llex (Eu- 
rasie) et Cerris (Eurasie) sont considérés comme appartenant à la section Quercus; ils mériteraient cependant d'être classés en sous-sections ou à un niveau supérieur après analyses complémentaires.

\section{Quercus / taxonomie / phylogénie / sous-genres / sections}

\section{INTRODUCTION}

Recent studies of the phylogeny of Quercus (Nixon, 1984, 1989) (Manos et al, KC Nixon, $P$ Manos, manuscripts in preparation) have provided the basis for a revised infrageneric classification of the genus. Quercus is most closely related to the recently discovered tropical genera Trigonobalanus Forman, Formanodendron Nixon and Crepet, and Colombobalanus Nixon and Crepet (Nixon, 1989; Nixon and Crepet, 1989). Cladistic analysis of 17 morphological characters (Nixon, 1984) (KC Nixon, $\mathrm{P}$ Manos, manuscript in preparation) has been undertaken in combination with chloroplast (cp) DNA restriction site analyses of 92 informative sites among 33 species of Quercus, Trigonobalanus and Colombobalanus (Manos et al, manuscript in preparation). The relationships of various groups within Quercus are summarized in figure 1, based on a combination of the morphological and molecular data analyses that will be presented elsewhere (KC Nixon, P Manos, manuscript in preparation). The morphological data set allowed greater resolution of among-section relationships, while the molecular data set added synapomorphies for sectional groups. In general, the results of these analyses support recognition of 4 monophyletic groups of oaks, the Cyclobalanopsis, the Lobatae (the red oaks, subg Erythrobalanus of recent literature), the Protobalanus (the intermediate oaks) and the white oaks in the

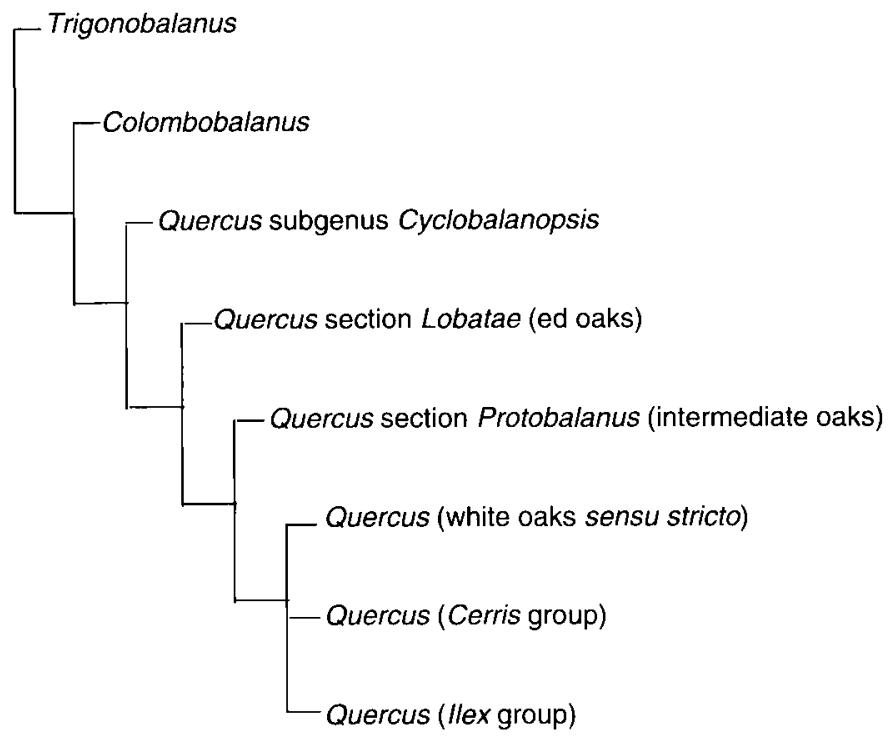

Fig 1. Proposed phylogenetic relationships of major infrageneric groups of Quercus. 
broad sense (variously referred to as Lepidobalanus, Euquercus, or Leucobalanus in recent literature). Note that the "Cerris" and "llex" groups are not recognized here as sections, and may merit recognition as subsections within section Quercus but the limits of these groups in terms of both species and characters is not clear at this time, particularly when the Asian species of Quercus are considered. Because of this uncertainty, I have chosen to defer a subsectional treatment within the white oaks until more data are available.

Because of the general similarity of the results of recent phylogenetic analyses to the previous classification proposed by $\mathrm{Ca}$ mus (1938), and in order to maintain the greatest level of taxonomic stability, I have followed her classification as closely as possible. However, Camus did not always adequately search for the earliest names at the sectional level in Quercus, and some of the names which she used must be replaced by earlier names. In particular, the sectional name of the red oak group must be changed to the oldest available name, Lobatae Loudon. In addition to the names accepted below, lectotypification of the sectional names proposed by Loudon (1830, 1835-1838) and others, even though they are treated as synonyms here, is important in order to stabilize the infrageneric nomenclature of Quercus. In all cases of lectotypification below, an attempt has been made, where possible, to lectotypify these names so that names currently and widely in use are not replaced. This has not been possible in all cases.

is it beyond the scope of this paper to exhaustively review the history of subgeneric and sectional names in Quercus, but the synonymy presented below includes all names which have been used extensively. I present here an infrageneric classification of the genus Quercus which broadly follows that of Camus, but utilizes Loudon's sectional names which have priority for some of the taxa Camus recognized. It is important to synonymize some of Loudon's sectional names which were published simultaneously.

\section{FOSSIL HISTORY}

The oldest unequivocal oak fossils are acorns, staminate catkins/pollen and compressed leaves from Oligocene deposits of North America (Daghlian and Crepet, 1983; Crepet, 1989; Crepet and Nixon, 1989a, b; Nixon and Crepet, 1989). Staminate catkins and stellate trichomes that resemble those of modern oaks are preserved in Baltic amber of northern Europe (Conwentz, 1986), but need further investigation, because they occur with fruits which appear to be trigonobalanoid.

Prior to the Oligocene, the oak lineage is represented by trigonobalanoid fossils consisting of well-preserved fruits and infructescences, pistillate and staminate inflorescences with in situ pollen, and associated 'Dryophyllum' type leaf compressions (Crepet and Nixon, 1989a, 1989b). While these fossils are not identical with modern trigonobalanoids, they share plesiomorphic features, such as several free triangular fruits in a valved cupule, capitate stigmas and cupules arranged along an elongate axis.

Throughout mid- and late-Tertiary deposits of the northern hemisphere, oak leaf compressions and impressions are abundant, and many of these, particularly from North America, have been identified as close relatives of modern species. Whether or not the Miocene and Pliocene species are as close to modern species as some authors have presumed, it is clear that by this time the oak flora had become prominent and diverse, and at least superficially resembled the assemblages seen in modern subtropical and temperate forests. 
Futher work is necessary to resolve the phylogenetic affinities of these abundant Tertiary oak leaf fossils.

\section{KEY TO THE SUBGENERA AND SECTIONS OF QUERCUS}

A. Stigmas capitate to subcapitate or discoid, styles generally terete without adaxial stigmatic groove; staminate catkins usually with prominent bracteoles, these subpersistent to caducous; scales of cupule in concentric or spiral rings, usually obviously connate laterally to form lamellae; east Asian. Subgenus Cyclobalanopsis.

AA. Stigmas usually linear ampliate or broadly ampliate, styles grooved, or with a short stigmatic groove extending from the stigma; staminate catkins with inconspicuous, caducous bracteoles, or these sometimes lacking; scales of cupule various, imbricately arranged and free; widespread in the northern hemisphere. Subgenus Quercus.

B. Base of pistillate perianth (perigon) free, forming a skirt or flange; styles usually elongate, linear-ampliate; endocarp always tomentose; cup scales typically flat, unkeeled; teeth of leaves if present usually aristate or spinose, rarely mucronate. Section Lobatae.

BB. Base of pistillate perianth (perigon) adnate to ovary/style bases, not forming a flange or skirt; styles elongate and linearampliate or short and broadly ampliate or cuneate; endocarp tomentose or glabrescent; cup scales typically keeled or tuberculate or both; teeth of leaves if present aristate, pungent, or mucronate.

C. Abortive ovules apical to lateral, rarely appearing basal; leaves persistent
2-3 years; acorn maturation biennial. Section Protobalanus.

cC. Abortive ovules always basal; leaves deciduous to subpersistent, rarely persistent for more than 1 year; acorn maturation biennial or annual. Section Quercus.

\section{TAXONOMIC TREATMENT OF QUERCUS}

\section{Quercus (oak, encino, chêne)}

Quercus L, Syst PI ed 2, II, 994. 1753. [for complete synonymy at the generic level, see Camus (1938)]. - Type: Quercus robur L (fide ING)

Trees or shrubs, flowers monoecious; wood ring-porous or diffuse-porous; terminal buds prominent, quadrangular to pentangular or rounded in cross-section; bud scales imbricate, bud stipules sometimes persistent; axillary buds often closely associated with and subtending terminal bud; leaves spirally arranged, craspedodromous, mixed craspedodromous or campylodromous, rarely bronchidodromous, often with parallel secondary veins, marginal teeth (if present) simple, aristate, mucronate or oblique, 1 associated with each secondary vein, or in some species the secondary vein branching and terminating in several teeth; staminate inflorescences lax-spicate (catkins), clustered at the base of new growth or occurring singly in the axils of some of the lower leaves, emerging at vernation; staminate flowers single or in groups of 1-3 along rachis, subtending bracteole prominent and often exceeding perianth and persistent past anthesis, or inconspicuous and caducous; stamens 6 (2-12), usually exserted at anthesis, surrounding a tuft of simple trichomes inter- 
preted as representative of a rudimentary pistillode: pollen tricolporate (-tricolpate), spheroidal to subprolate or suboblate, exine sculpture generally rugulate or scabrate, often microscabrate; pistillate inflorescence borne in the axils of leaves of young branches, usually stiff, with 1several partial influorescences, each subtended by a cupule, only the single central flower of each influorescence developing; pistillate perianth cupped to campanulate or rotate, shallowly to deeply 5-6 lobed, or the lobes obscure, basally adnate to the ovary or free; ovary $3(-6+)$ carpellate, inferior; styles $3(-6+)$, linear or subsessile, stigmas capitate to linear-ampliate and extending along adaxial stylar suture; fruit an acorn, a single rounded indehiscent nut subtended by a cupule that lacks suture zones and does not separate into valves, cupule with external imbricate or concentric scales, the 2 lateral abortive flowers of the partial influorescence within the cupule; fruit maturation biennial or annual, or occasionally 'pseudoannual' as in some species of section Protobalanus; endocarp sericeo-tomentose to glabrescent, columella and remnants of the septa of the carpels often impressed on the seed, forming irregular longitudinal grooves; seed coats usually brownish, adhering tightly to the seed at maturity or adhering to the endocarp wall; cotyledons free or sometimes fused completely: abortive ovules apical, lateral or basal; cupule scales arranged in concentric rows and partially or wholly connate laterally, to form concentric lamellae, or imbricate and free, sometimes reflexed and spinose. $n=12$.

Distribution: north temperate and subtropical, tropical montane, and particularly in Asia sometimes lowland tropical (subgenus Cyclobalanopsis); the greatest concentrations of species are in eastern North America (ca 60), highland Mexico and central America (150-200), and montane subtropical Eurasia from the Middle East to
China and southeast Asia (150?); fewer species are found in the western United States (ca 25) and temperate Europe and North Africa (8-12?); 1 species is found in northern South America (Colombia).

\section{Subgenus Cyclobalanopsis - (cycle-cup oaks)}

Quercus subgenus Cyclobalanopsis (Oersted) Schneider, Handb Laubh, I, 210. 1906.

- Cyclobalanopsis Oersted (as genus), Bidrat til Kundskab om Egefamilien, 69. 1871. -Quercus section Cyclobalanopsis Bentham and Hooker, Gen PI III, I p 408. 1880. -Type: Quercus velutina Lindley ex Wallich, non Lamarck. (fide ING)

Trees or shrubs; bark usually smooth or furrowed, hard, gray or black, rarely lightcolored; leaves persistent or subpersistent, entire or serrate-toothed, teeth if present mucronate or rarely setate; foliar trichomes thin-walled and glandular, uniseriate, fasciculate, multiradiate or rosulate, rarely if ever thick-walled and/or stellate; staminate flowers usually distributed in groups of 1-3 along rachis, subtending bracteole usually prominent and often exceeding perianth and persistent, staminate perianth often regularly 6-lobed; anthers apiculate or retuse; pollen exine sculpture typically rugulate, often microscabrate; pistillate perianth 5-6 lobed, base adnate to ovary; styles 3 $(-6+)$, usually linear with an expanded flat or subcapitate stigma, the stigmatic surface extending only partially along stylar suture or sometimes not extending along suture at all, in any case not forming a prominent stigmatic groove; stylopodial umbo often annulate with 1-3 (-5) distinct rings; fruit maturing the 2 season or in the 1 year, but at least sometimes 'pseudoannual' as in some species of section Protobalanus; endocarp sericeo-tomentose, remnants of the septa of the carpels often 
impressed on the seed, forming irregular longitudinal grooves, or subglabrous; seed coats usually brownish, adhering tightly to the seed at maturity or adhering to the endocarp wall; cotyledons free; abortive ovules apical; cupule scales arranged in concentric or spiral rows and partially or wholly connate laterally, to form concentric lamellae, often densely vestitured.

Distribution: subtropical, montane tropical and lowland tropical east Asia and Malaysia.

I recognize the possible utility of generic rank for Cyclobalanopsis as proposed by Schwarz (1936). Until careful studies produce stronger evidence that Quercus as broadly defined is polyphyletic, the conservative stance of recognizing a single genus is appropriate.

\section{Subgenus Quercus: (scale-cup oaks)}

\section{Quercus subgenus Euquercus (Hickel and Camus) A Camus, Les Chênes. Monographie du genre Quercus. Vol I. 373. 1938}

Large trees, shrubs or sometimes low rhizomatous shrubs; bark variable, from smooth to scally or furrowed; leaves persistent, subpersistent or deciduous, entire, serrate-toothed or lobed, teeth if present setate, aristate, pungent or mucronate; foliar trichomes thin-walled and glandular, uniseriate, fasciculate, multiradiate or rosulate, and/or thick-walled and/or stellate; staminate flowers distributed singly along rachis, the single subtending bracteole caducous or sometimes lacking, staminate perianth irregularly or regularly 2-6 lobed; anthers retuse, or with an apiculate or attenuate connective; pollen exine sculpture typically scabrate with obscure or obvious perforations; styles $3(-6+)$, with expanded stigmatic surface, capitate to linear ampliate with an adaxial stigmatic groove; stylo- podial umbo often annulate with 1-3 (-5) distinct rings; fruit solitary in each cupule, rounded in cross-section, maturing the 1 or 2 season; abortive ovules apical, or in some species variable in position or basal; cupule hemispheric, cup-shaped to flat; $\underline{\mathrm{cu}-}$ pule scales variable, spirally or concentrically arranged; laterally connate or free.

I follow Camus in her broad interpretation of subgenus Quercus, to include all oak species except the Cyclobalanopsis group, although American workers usually recognize 3 subgenera in North America. Camus' classification is compatible with results of phylogenetic analyses. Certain Eurasian oaks (eg $Q$ coccifera) as well as Protobalanus are morphologically 'intermediate' in certain characters between red oaks and white oaks sensu stricto, and this further supports the closer relationship of these oaks to each other than to Cyclobalanopsis. If Cyclobalanopsis is included in Quercus as a subgenus, prudence recommends that the remainder of Quercus be accomodated in a single subgenus. The 3 major groups of oaks in North America may then be recognized as sections (see below).

\section{Quercus subgenus Quercus section Lobatae (red oaks)}

Quercus section Lobatae Loudon, Hort Brit 385. 1830. Lectotype (here chosen): Quercus aquatica Walt (= $Q$ nigra $L$ ). The 4 species which Loudon included in this section are red oaks. This eliminates any possibility of lectotypifying the section so that it is a synonym of the 'type' section, the white oaks. Thus, this name must stand as the earliest name for the red oaks if they are recognized at the level of section.

Quercus section Integrifoliae Loudon, Hort Brit 384. 1830. Lectotype (here chosen): Quercus phellos L. 
Quercus section Mucronatae Loudon, Hort Brit 385. 1830. Lectotype (here chosen): Quercus rubra L.

Quercus section Rubrae Loudon, Arbor Frut Brit 3, 1877. [1835-]1838. - Type: Quercus rubra L. Loudon's concept of $Q$ rubra was that of the northern red oak, not of the southern red oak ( $Q Q$ falcata), as the name $Q$ rubra was applied by some later authors (eg Sargent, 1922).

Quercus section Nigrae Loudon, Abor Frut Brit 3, 1980. [1835-]1838. - Type: $Q$ nigra L. Loudon followed Michaux in his concept of $Q$ nigra as the blackjack oak (= $Q$ marilandica), but included the real $Q$ nigra in this section as $Q$ aquatica.

Quercus section Phellos Loudon, Arbor Frut Brit 3, 1894. [1835-]1838. - Type: Quercus phellos L.

Quercus section Erythrobalanus Spach, Hist veg Phan 11, 160. 1842. - Quercus subgenus Erythrobalanus (Spach) Endlicher, Gen Plant suppl 4, 24. 1847. - Quercus subsection Erythrobalanus (Spach) Post and Kuntze, Lexicon generum Phaner 474. 1904. - Genus Erythrobalanus (Spach) Schwarz, Notizbl Bot Gard Berlin 13, 8. 1936. Lectotype (here chosen): Quercus rubra L.

Quercus subgenus Melanobalanus Engelman, Trans St Louis Acad Sci 3, 388. 1877.

Large trees, shrubs or sometimes low rhizomatous shrubs; bark usually smooth or furrowed, hard, gray or black, rarely light-colored; leaves persistent, subpersistent, or deciduous, entire, serrate-toothed or lobed, teeth if present usually aristate or setate, a terminal seta often present even on untoothed leaves; foliar trichomes thinwalled and glandular, uniseriate, fascicu- late, multiradiate or rosulate, rarely if even thick-walled and/or stellate; staminate flowers usually distributed singly along rachis, subtending bracteole caducous or lacking, staminate perianth irregularly, often deeply 2-6 lobed; anthers usually somewhat apiculate, occasionally retuse; pollen exine sculpture typically rugulate and microscabrate to scabrate; pistillate perianth 5-6 lobed, the base not adnate to the ovary, therefore forming a minute free skirt or flange, the inner cupule scales often inserted beneath this flange; styles $3(-6+)$, linear-spatulate, the stigmatic surface extending proximally along stylar suture, forming a darkened stigmatic groove; stylopodial umbo often annulate with 1-3 (-5) distinct rings; fruit maturing the 2 season, or in several species in the 1 year; endocarp sericeo-tomentose, remnants of the septa of the carpels often impressed on the seed, forming irregular longitudinal grooves; seed coats reddish or brownish, adhering tightly to the seed at maturity; cotyledons free or rarely partially connate; abortive ovules apical, or rarely in some species variable in position or subbasal; cupule scales thin, flat, only rarely keeled or tuberculate, imbricate, never spinescent.

Distribution: restricted to temperate, subtropical and montane tropical parts of the new world, from Colombia, South America (1 $\mathrm{sp}$ ) through central America to forests of southeastern Canada, and westward to southern Oregon; largely absent from the Rocky Mountain area, except for Arizona and New Mexico.

\section{Quercus subgenus Quercus section Protobalanus (intermediate oaks, golden cup oaks)}

Subgenus Protobalanus Trelease, in Standley, Contr U S Natl Herb 23, 176. 1922. Quercus section Protobalanus (Trelease) 
Schwarz, Notizb/ Bot Gart Berlin 13, 21. 1936. - Quercus section Protobalanus (Trelease) Camus, Les Chênes, vol 1, 157. 1938. - Type: Quercus chrysolepis Liebm. Both Camus and Schwarz interpreted Trelease's Protobalanus as a section, and attributed this rank to Trelease. Confusion regarding the original rank of this name apparently arose from ambiguity in Trelease's presentation of the name in his 1924 monograph. Trelease used several infrageneric names that had been proposed by earlier authors, eg, Leucobalanus Engelmann, without reference to the original authority, publication, or rank at which the names were published. Protobalanus was presented in the 1924 monograph in a similar 'naked' manner, leading later authors to believe that this was the original publication of the name. However, the first use by Trelease of the name Protobalanus dates to 1916 in Proc Natl Acad Sci 2,627 , where he clearly referred to it as a subgenus, as well as referring to the type of Protobalanus as $Q$ chrysolepis (loc cit, $\mathrm{p}$ 629). Protobalanus was again used by Trelease in 1918 (Brooklyn Bot Gard Mem 1, 497), and again in Standley's Trees and Shrubs of Mexico, 1922. No description appeared in the earlier publications, but in the latter, Trelease included the name in a key to the species of Mexico, with clear diagnostic characters. The 1922 publication therefore must be considered the first valid publication of the name, and there is no ambiguity in the earlier publications as to the rank (subgenus) at which the name was intended.

Evergreen shrubs or trees, bark usually scaly and rough (as in various white oaks) on older branches; twigs tomentose to glabrous; leaves persistent 2 or more years coriaceous, glaucous and waxy on the abaxial surface, entire or toothed, often spinescent, never lobed as in $Q$ robur, foliar trichomes thin-walled, semi-glandular, simple or with 2-several fasciculate single- celled rays emerging from the epidermis together, or multicellular glandular uniseriate; staminate flowers with 4-12 stamens, the anthers apiculate; pollen exine sculpture rugulate to scabrate, with nanno-striae on rugulae; (fide Solomon, 1983a, 1983b); pistillate flowers 1-3, usually sessile, peduncule sometimes developed; styles short and ampliate to long with ampliate stigma ( $Q$ palmeri); fruit maturing in 2nd year, but often the fertile branches do not grow in 2nd year, so that the fruit may appear annual (pseudoannual maturation); endocarp tomentose to appearing glabrous, the seed coats usually attached to the seed but sometimes attached to the endocarp; cotyledons furrowed, subequal.

Distribution: western North America from southern Oregon, south to northern Baja California, Mexico, eastward to central Arizona, and barely into adjacent Chihuahua; also present on the channel islands of southern California, and the only group of oaks present on the islands of Guadalupe and Cedros off the coast of Baja California.

Protobalanus is a distinctive group of about 5 species, 1 of which ( $Q$ chrysolepis Liebm) is widely distributed and highly variable. The distribution of this group, which is restricted to western North America, suggests a possible common biogeographical history with Lithocarpus densiflora and Chrysolepis sempervirens and $C$ chrysophylla of the California region. The latter 3 species are apparently relicts of a previously richer Asian element in western North America that is no longer prevalent. Protobalanus is undoubtedly the most interesting group of oaks in North America from the standpoint of phylogeny and biogeography. The phylogenetic affinities of this distinctive and unique group are uncertain, although for the present, Protobalanus must be considered a part of the nominal subgenus. They appear to be closely related to but intermediate between the red oaks and the white oaks. In this respect, 
Protobalanus closely parallels the somewhat intermediate groups of Eurasian oaks that center around $Q$ cerris, $Q$ suber, and $Q$ coccifera. Protobalanus species appear to be strongly reproductively isolated from the other groups of North American oaks, as no verified natural or artificial hybrids are known.

\section{Quercus subgenus Quercus section Quercus (white oaks)}

Quercus section Dentatae Loudon, Hort Brit 384. 1830. Lectotype (here chosen): Quercus prinus L. Loudon included a broad array of white oaks, including both American and Eurasian species, in this section.

Quercus section Ilex Loudon, Arbor Frut Brit 3, 1899. [1835-]1838 . Type: Quercus ilex L.

Quercus section Cerris Loudon, Arbor Frut Brit 3, 1730. [1835-]1838. - Type: Quercus cerris L.

Quercus section Albae Loudon, Arbor Frut Brit 3, 1730, 1863. [1835-]1838. Type: Quercus alba L.

Quercus section Robur Loudon, Arbor Frut Brit 3, 1730, 1731. [1835-]1838. Type: Quercus robur $\mathrm{L}$.

Quercus section Prinus Loudon, Arbor Frut Brit 3, 1730, 1872. [1835-]1838. Type: Quercus prinus L.

Quercus section Lanatae Loudon, Arbor Frut Brit 3, 1730, 1920. [1835-]1838. Type: Quercus lanata Smith.

Quercus section Virentes Loudon, Arbor Frut Brit 3, 1730, 1918. [1835-]1838. Type: Quercus virens Aiton.
Quercus section Lepidobalanus Endlicher, Gen Plant, suppl 4, part 2, p 24. 1847, pro parte. Lectotype (here chosen): Quercus robur L.

Quercus section Leucobalanus Engelmann, Trans Acad Sci St Louis 3, 381. 1876.

Quercus section Mesobalanus Camus, Monographe Genre Quercus, Atlas I, p 49. 1936.

Quercus section Euquercus Hickel and Camus, Ann Sci Nat Bot, 9e ser. Ill, p 379. 1921. - Type: Quercus robur L.

Quercus subgenus Heterobalanus Oersted, Bidr til Kundskab Om Engefamilien. 1871

Trees or shrubs: bark smooth, rough, scaly or flaky, relatively soft, occasionally hard and furrowed; leaves persistent, subpersistent, or deciduous, entire, serratetoothed or lobed, teeth if present mucronate, pungent, or sometimes on juvenile growth aristate, or rarely (Cerris and Ilex groups) consistently aristate; foliar trichomes thin-walled and glandular, uniseriate, fasciculate, multiradiate or rosulate, and often thick-walled and/or stellate; staminate flowers usually distributed singly along rachis, subtending bracteole caducous or lacking, staminate perianth regularly to irregularly, often deeply 2-6 lobed; anthers usually retuse, rarely apiculate; pollen exine sculpture scabrate or rugulate-scabrate; pistillate perianth 5-6 lobed, the base adnate to the ovary; styles 3($6+$ ), usually abruptly ampliate or dilated, sometimes more gradually ampliate or subulate, stigmatic surface extending proximally along stylar suture, the stigmatic surface often cuneate in shape; stylopodial umbo usually not annulate; fruit maturing in the 1st year, occasionally (Ilex and Cer- 
ris) maturing in the 2nd year; endocarp glabrate or with minute tomentose vestiture near apex and base, but obscured by the adhering seed coats, or occasionally (I/ex and Cerris) tomentose-sericeous; columellar scar typically not present on lateral part of seed or endocarp; seed coats at maturity adhering to endocarp, or (Ilex and Cerris) to seed; cotyledons equal or unequal, free, or connate (Virentes and Glaucoideae); abortive ovules basal; cupule scales keeled or tuberculate, imbricate, usually with thickened corky base, sometimes reflexed and spinescent.

Distribution: the most widespread section of Quercus, occurring throughout favorable habitats in temperate, subtropical and tropical montane parts of North and Central America, Europe and (extratropical) Asia.

It is clear, based on morphological and molecular data, that the Cerris and Ilex groups of oaks are part of the broader white oak group, sharing the synapomorphy of basal abortive ovules. Because the exact relationships of these groups are uncertain (Ilex may be paraphyletic to one or more other groups within the white oaks), it seems best at this time to recognize only one section for the white oaks sensu lato. As more data within the white oaks become available, a subsectional classification will be proposed, and the variation encompassed by the Ilex, Cerris, Virentes, Glaucoideae and other groups of white oaks can be formally recognized based on phylogenetic pattern.

\section{REFERENCES}

Camus A (1938) Les Chênes. Monographie du Genre Quercus. 2 vols. Lechevalier and Fils, Paris (cited as 1936-1938, but not released until 1938, fide Stafleu and Cowan, 1976)

Conwentz H (1986) Die flora des Bernsteins, Zweiter Band; Die Angiospermen des Bernsteins. Engelmann, Danzig
Crepet WL (1989) History and implications of the early North American fossil record of Fagaceae. In: Evolution, Systematics, and Fossil History of the Hamamelidae. Vol 2. 'Higher' Hamamelidae (Crane PR, Blackmore S, eds), Clarendon Press, Oxford, 45-66

Crepet WL, Nixon KC (1989a) Eearliest megafossil evidence of Fagaceae: phylogenetic and biogeographic implications. Am J Bot 76, 842-855

Crepet WL, Nixon KC (1989b) Extinct transitional Fagaceae from the Oligocene and their phylogenetic implications. Am $J$ Bot 76 , 1493-1505

Daghlian CP, Crepet WL (1983) Oak catkins, leaves, and fruits from the Oligocene Catahoula Formation and their evolutionary significance. Am J Bot 70, 639-649

Loudon J (1830) Hortus Brittanicus. Longman, Rees, Orme, Brown and Green, London

Loudon J (1835-1838) Arboretum et Fruticetum Botanicum. Longman, Rees, Orme, Brown and Green, London

Nixon KC (1984) A Biosystematic Study of Quercus Series Virentes with Phylogenetic Analyses of Fagales, Fagaceae and Quercus. Ph D Dissertation, University of Texas, Austin

Nixon KC (1989) Origins of Fagaceae. In: Syst Assoc Spec vol 40B. Evolution, Systematics and Fossil History of the Hamamelidae. Vol 2 (Crane PR, Blackmore S, eds) Clarendon Press, Oxford, 23-43

Nixon KC, Crepet WL (1989) Trigonobalanus (Fagaceae): taxonomic status and phylogenetic relationships. Am J Bot 76, 826-841

Sargent CS (1922) Manual of the Trees of North America (Exclusive of Mexico). Houghton Mifflin Co, New York

Schwarz O (1936) Entwurf zu einem naturlichen System der Cupuliferen und der Gattung Quercus L. Notizbl Bot Gart Berl 13, 1-22

Solomon AM (1983a) Pollen morphology and plant taxonomy of white oaks in eastern North America. Am J Bot 70, 481-494

Solomon AM (1983b) Pollen morphology and plant taxonomy of red oaks in eastern North America. Am J Bot 70, 495-507

Stafleu FA, Cowan RS (1976) Taxonomic Literature. 2nd edn, vol 1. Bohn, Scheltema and Holkema, Utrecht 